\title{
Seed Transmission of Cucumber Mosaic Virus in Spinach
}

\author{
Yanming Yang, Kyung Soo Kim, and Edwin J. Anderson
}

Department of Plant Pathology, University of Arkansas, Fayetteville 72701.

Accepted for publication 9 June 1997.

ABSTRACT

\begin{abstract}
Yang, Y., Kim, K. S., and Anderson, E. J. 1997. Seed transmission of cucumber mosaic virus in spinach. Phytopathology 87:924-931.

Spinach (Spinacia oleracea) seed from a commercial breeding line suspected of harboring cucumber mosaic virus (CMV) was analyzed for seed transmission of the virus. Initial seed grow-out tests and enzymelinked immunosorbent assay studies indicated that CMV was present in this seed lot at a level of nearly $15 \%$. To verify these results and gain insight into the mechanism of seed transmission, four combinations of crosses between healthy and/or infected parent plants were conducted. None of the spinach seedlings derived from crossing healthy male and healthy female plants contained CMV, whereas a portion of seedlings derived from all of the other three crosses, i.e., healthy male and infected female, infected male and healthy female, and infected male and infected female plants, were infected with CMV. The results demonstrate that CMV is seed transmitted in spinach and indicate that both male and female parent plants can serve as infection sources. Ultrastructural studies, including immunogold labeling, revealed the presence of virus particles
\end{abstract}

in the cytoplasm of ovary wall cells, ovule integuments and nucellus, anther, and seed-coat cells, as well as fine fibril-containing vesicles and electron-dense inclusions of amorphous aggregates in the central vacuoles of these cells. In addition, reverse transcription-polymerase chain reaction (RT-PCR) was used to amplify 860 -bp cDNA fragments containing the CMV coat protein $(\mathrm{CP})$ gene from the embryo, endosperm, and pollen tissues of CMV-infected plants. Taken together, these studies indicate that CMV occurs in virtually all spinach reproductive tissues. Analysis of several RT-PCR amplified and cloned CP genes and flanking sequences from parent and progeny plants revealed that the spinachinfecting CMV was a member of subgroup II. Furthermore, cDNA sequencing and restriction endonuclease mapping consistently revealed two sequence variants, designated SP103 and SP104, in most plants analyzed. These data suggest that there may have been mixed infections of two distinct, seed-transmitted CMV variants in spinach.

Additional keyword: electron microscopy.
Cucumber mosaic virus (CMV), the type member of the plant cucumovirus group, has a wide host range and infects a great variety of important crop plants, making it one of the most economically significant plant viruses (24). Under natural conditions, CMV generally is transmitted by aphids (10), but the virus also has been transmitted by seed in some plant species (22). Reported CMV seed infection rates range from $0.7 \%$ in pumpkin (Cucurbita pepo) (33) and $7 \%$ in bean (Phaseolus vulgaris) (1) to $55 \%$ in wild cucumber (Echinocystis lobata) (6). In many plant virus systems, transmission of viruses through seed, even at a very low rate, can be important for virus perpetuation and dissemination and provides an inoculum source that may have a considerable impact on crop production. For example, seed transmission contributes to the economic problems caused by barley stripe mosaic hordeivirus, pea seed-borne mosaic potyvirus, lettuce mosaic potyvirus, tomato black ring nepovirus, and raspberry ringspot nepovirus (35). Furthermore, seed transmission is an effective survival strategy for viruses, especially for those with narrow host ranges, those that infect annual plants, and those that are vectored in a nonpersistent manner (17).

A large number of CMV strains have been isolated $(18,30)$. Based on serological typing (4), peptide mapping of the coat protein (CP) (8), and nucleic acid hybridization $(13,23,27)$, these strains have been differentiated into two subgroups, I and II. Due

Corresponding author: E. J. Anderson

E-mail address: eanderso@uafsysb.uark.edu

The nucleotide sequence data have been deposited in the GenBank Sequence Database under the accession numbers U10923 for CMV-SP103 and U10924 for CMVSP104.

Publication no. P-1997-0714-01R

(C) 1997 The American Phytopathological Society to the availability of nucleotide sequence information, CMV isolates can be more precisely differentiated by analyzing and comparing the $\mathrm{CP}$ gene and its untranslated flanking regions $(28,30)$. Comparisons have shown that members of the same subgroup share greater than 90 to $95 \%$ sequence identity and possess only 70 to $75 \%$ homology with members of the other subgroup.

Although seed transmission of CMV has been well documented in a number of plants, including many common weeds, to date seed transmission of CMV has not been reported in spinach (Spinacia oleracea L.), a dioecious vegetable crop that is subject to significant losses due to CMV infection. Recent observations of greenhouse- and field-grown spinach plants suggest that seeds from a few spinach breeding lines may be transmitting the virus, but until now, no experimental evidence has corroborated these observations. We report here that CMV is seed transmitted in one spinach breeding line at a significantly high level and that the virus is a member of subgroup II. To understand the mechanism of viral seed transmission in this crop, studies were undertaken, both to determine whether the virus is derived from maternal, paternal, or both tissue types and to localize the virus in infected seed. To our knowledge, this is the first confirmation of CMV seed transmission in spinach. Preliminary presentations of some of these data have been made $(42,43)$.

\section{MATERIALS AND METHODS}

Plant materials. Seed from two spinach breeding lines suspected of CMV infection was germinated in large flats containing Redi-Earth 3CF potting mixture (Grace Sierra, Milpitas, CA). Plants were either grown in a growth chamber with a 10 -h day at $21^{\circ} \mathrm{C}$ or in a greenhouse with a 9- to 11 -h day at temperatures ranging from 20 to $30^{\circ} \mathrm{C}$. The plants were carefully monitored to ensure they remained free of aphids. 
Enzyme-linked immunosorbent assay (ELISA) determination of seedling infection by CMV. When spinach seedlings reached the 5-leaf stage, the plants were sampled by harvesting $\sim 1.5 \mathrm{~g}$ of mature leaf tissue. Plant sap was extracted and diluted 1:10 with phosphate buffered saline-Tween buffer (PBST; $137 \mathrm{mM}$ $\mathrm{NaCl}, 1.5 \mathrm{mM} \mathrm{K} \mathrm{HPO}_{4}, 8 \mathrm{mM} \mathrm{Na} \mathrm{HPO}_{4}, 2.7 \mathrm{mM} \mathrm{KCl}, 0.05 \%$ [vol/vol] Tween 20, pH 7.4). CMV was detected by protein A sandwich indirect ELISA (PAS-ELISA) $(9,39)$. CMV polyclonal antiserum $(1: 10,000$ in PBST) was used in the detection procedure. Alkaline phosphatase substrate ( $p$-nitrophenyl phosphate, disodium; Sigma Chemical Co., St. Louis) was added, and the reaction was quantitated by determining absorbance at $405 \mathrm{~nm}$ with a microplate reader (Cambridge Technology Inc., Watertown, MA). A sample was considered positive for CMV infection when the mean absorbance of two replicates was three times greater than the absorbance of the uninfected plant controls.

CMV transmission through seed. CMV-infected and healthy spinach plants, determined by ELISA, were separated and grown in different greenhouses. Immediately before flowers began to emerge, plants were tested again by ELISA to confirm their healthy or infected status. After plants were identified as male or female, they were divided into four groups: healthy male, healthy female, infected male, and infected female. Four combinations of plant crosses were carried out: (i) healthy male and healthy female, (ii) healthy male and infected female, (iii) infected male and healthy female, and (iv) infected male and infected female. Each cross consisted of 5 to 10 maternal and paternal plants, respectively. The tests were conducted in separate greenhouses to prevent uncontrolled cross-pollination. Approximately 50 to 100 seeds derived from each of 5 to 10 maternal plants per cross were harvested and grown separately in large flats as described above. When the seedlings reached the 5-leaf stage, leaf tissues were harvested from each plant for PAS-ELISA determination of CMV infection.

Electron microscopy. Anther, ovary wall, and ovule tissues were collected from CMV-infected spinach plants before pollination for ultrastructural investigation. Similar studies were carried out with green, nondehydrated, mature seeds. Pieces $\left(\sim 0.5 \mathrm{~mm}^{2}\right)$ of all sampled tissues were fixed in modified Karnovsky's fixative (2\% glutaraldehyde and $2 \%$ paraformaldehyde in $0.05 \mathrm{M}$ cacodylate buffer, $\mathrm{pH}$ 7.0) for $2 \mathrm{~h}$ at room temperature under low vacuum (19). After washing three times with cacodylate buffer, tissues were postfixed in $1 \% \mathrm{OsO}_{4}$ in cacodylate buffer for $2 \mathrm{~h}$ and bulk stained in $0.05 \%$ aqueous uranyl acetate overnight at $4^{\circ} \mathrm{C}$. The tissues were dehydrated in an ethanol series and propylene oxide before being embedded in Spurr's low-viscosity embedding medium (34). Thin sections cut with a diamond knife were double stained with $2 \%$ uranyl acetate for $5 \mathrm{~min}$ and $12 \%$ lead citrate for 2 min before being examined under a JEOL (Tokyo) $100 \mathrm{CX}$ electron microscope.

Immunogold labeling. After fixation in modified Karnovsky's fixative, tissues were washed with $0.05 \mathrm{M}$ cacodylate buffer two times for $20 \mathrm{~min}$ each and further washed overnight. Tissues were dehydrated in a series of 30,50 , and $70 \%$ ethanol, treated with a 2:1 ratio of LR White resin (London Resin Co. Ltd., Basingstoke, England) $/ 70 \%$ ethanol, and infiltrated in freshly prepared LR White for $1 \mathrm{~h}$. Tissues were embedded in fresh LR White and stored at $50^{\circ} \mathrm{C}$ for $24 \mathrm{~h}$ for polymerization. Thin sections were processed in a blocking solution of $8 \%$ nonfat dry milk in PBST ( $\mathrm{pH} \mathrm{7.3)} \mathrm{and}$ incubated with anti-CMV polyclonal antibody solution (1:800 in PBST) for $1 \mathrm{~h}$ at room temperature. The sections were washed with PBST and incubated in a solution of anti-rabbit immunoglobulin G-gold conjugate (Sigma) diluted 1:300 in PBST. After washing thoroughly with PBST buffer, the sections were poststained with $2 \%$ uranyl acetate for $5 \mathrm{~min}$ and lead citrate for $2 \mathrm{~min}$ before being examined under an electron microscope.

Preparation of total nucleic acid and amplification of the CMV CP gene. Leaf, pollen, embryo, and endosperm tissues from CMV-infected plants were used for total nucleic acid extraction.
Tissue samples $(\sim 0.1$ to $0.2 \mathrm{~g})$ were placed in $1.5-\mathrm{ml}$ microcentrifuge tubes, frozen in liquid nitrogen, and thoroughly ground. Total nucleic acid was extracted according to the method of Pappu et al. (25). Extraction buffer (2\% sodium dodecyl sulfate, $0.1 \mathrm{M}$ Tris-Cl, 2 mM EDTA, $\mathrm{pH}$ 8.0) and phenol/chloroform/isoamyl alcohol $(25: 24: 1)$ were added to the ground samples. The mixtures subsequently were heated to $70^{\circ} \mathrm{C}$ for $5 \mathrm{~min}$ and centrifuged for $5 \mathrm{~min}$ at $4^{\circ} \mathrm{C}$ to obtain a crude nucleic acid preparation. Eluate collected from a Sephadex G-50 (Sigma) column was placed on ice and used as a template source for reverse transcription-polymerase chain reaction (RT-PCR) amplification of the CMV CP gene and flanking sequences. Nucleic acid extracts from the leaves and pollen of healthy plants, as well as extracts from embryo and endosperm tissues of a CMV-free breeding line, were used as negative controls, whereas nucleic acid extracted from spinach leaves with known CMV infections was used as a positive control.

A virus-specific cDNA fragment was amplified from total nucleic acid derived from CMV-infected tissues by a RT-PCR method as described by Pappu et al. (25). A primer pair specific to sequences flanking the CMV CP gene was synthesized commercially (Genosys Biotechnologies Inc., The Woodlands, TX). The $5^{\prime}$ primer (CMVCP 5') sequence, 5'-TTCTCCGCGAGTTAGC-3', corresponded to residues 1151 to 1166 in CMV-Q RNA 3 (3), whereas the $3^{\prime}$ primer (CMVCP 3') had a sequence of 5'-CGTAAGCTGGATGGAC-3', which is complementary to residues 1998 to 2013. This primer pair was selected because the $5^{\prime}$ primer was identical to published information for CMV subgroup II members and had only two internal mismatches compared to CMV subgroup I members (30). The 3' primer was complementary to several subgroup I and II members $(29,30)$.

The RT-PCR reaction mixture $(100 \mu \mathrm{l})$ contained $100 \mathrm{pmol}$ each of CMVCP 5' and CMVCP 3', $10 \mathrm{mM}$ dithiothreitol, $0.4 \mathrm{mM}$ of each dNTP, $1 \mathrm{mM} \mathrm{MgCl}_{2}$, 32 units of rRNasin (Promega, Madison, WI), 16 units of avian myeloblastosis virus reverse transcriptase, and 2.5 units of Taq DNA polymerase (Promega). Heatdenatured nucleic acid was added to the reaction mixture, which was incubated at $42^{\circ} \mathrm{C}$ for $1 \mathrm{~h}$ to allow first-strand cDNA synthesis. Samples were placed in a thermocycler (Barnstead/Thermolyne Corporation, Dubuque, IA) programmed for 2 min at $94^{\circ} \mathrm{C}$, followed by 35 cycles of $93.5^{\circ} \mathrm{C}$ for $45 \mathrm{~s}, 45^{\circ} \mathrm{C}$ for $45 \mathrm{~s}$, heat ramp to $72^{\circ} \mathrm{C}$ over $2.5 \mathrm{~min}$, and $72^{\circ} \mathrm{C}$ for $1 \mathrm{~min}$. A final 5 -min incubation at $72^{\circ} \mathrm{C}$ was followed by holding samples at $5^{\circ} \mathrm{C}$ until they could be removed from the thermocycler. PCR products were resolved by $1 \%$ agarose gel electrophoresis and visualized by ethidium bromide staining.

cDNA cloning, sequencing, and restriction endonuclease mapping. The cDNAs representing the CMV CP gene and flanking sequences were recovered by excising ethidium bromide-stained cDNA bands from $0.8 \%$ low melting point agarose gels. These were blunt-ended with the large fragment of DNA polymerase I (Promega), phosphorylated with T4 polynucleotide kinase (Promega), and cloned into the SmaI site of pUC118 $(25,31)$. The resulting plasmids were used to transform Escherichia coli DH5 $\alpha$ by the $\mathrm{CaCl}_{2}$ method (31). The transformed bacteria were cultured on solid $2 \times$ YT medium, containing $75 \mu \mathrm{g}$ of ampicillin per $\mathrm{ml}, \mathrm{X}$ Gal (5-bromo-4-chloro-3-indolyl- $\beta$-D-galactoside), and IPTG (isopropylthio- $\beta$-galactoside; U.S. Biochemical, Cleveland), and incubated at $37^{\circ} \mathrm{C}$ for $15 \mathrm{~h}$. White colonies were cultured further in liquid $2 \times$ YT medium, and the plasmids were purified by the boiling method described by Sambrook et al. (31). The plasmids were digested with EcoRI and PstI (Promega) according to the supplier's recommendation. The presence of cDNA inserts was determined by agarose gel electrophoresis and ethidium bromide staining.

The nucleotide sequences of CMV CP gene inserts were determined by the dideoxynucleotide chain termination method (32), using Sequenase, version 2.0 (U.S. Biochemical) according to the manufacturer's recommendation. In all, 14 cDNA clones derived 
from three $\mathrm{CMV}$-infected spinach parent plants were sequenced. After determining the nucleotide sequences, the computer program PC/GENE (IntelliGenetics, Mountain Review, CA) was employed for sequence comparisons of these clones with other known strains of the virus. Preliminary sequence analysis consistently revealed only two sequence variants. Furthermore, these studies revealed a unique $M l u \mathrm{I}$ restriction endonuclease site within the $\mathrm{CP}$ gene of one sequence variant, which could be used to differentiate the CMV variants under investigation. Based on the initial sequence and restriction endonuclease analyses, identification and classification of additional $\mathrm{CP}$ gene-containing clones were accomplished by $M l u I$ mapping and agarose gel electrophoresis. With this approach, 32 more clones from 5 parent plants and 20 clones from 2 progeny plants were screened without further cDNA sequencing.

\section{RESULTS}

CMV seed transmission in spinach. Seed transmission of CMV in spinach was determined by seed grow-out tests and ELISA. Results indicated that seedlings from one suspect breeding line were free of CMV infection (data not shown). However, when 536 seedlings from another breeding line were analyzed in five experiments, 79 seedlings harbored the virus, corresponding to an average infection incidence of $14.8 \%$ (Table 1). Because the seed had been germinated and plants had been carefully grown under conditions that ensured isolation from outside sources of CMV and aphid vectors, these results demonstrate that CMV was seedborne in the spinach.

To confirm that CMV was seed transmitted in spinach and to better understand the mechanism of transmission, four combinations of crosses between healthy and infected parent plants were conducted. The results of ELISA analysis on the progeny plants from each cross indicated that the spinach seedlings derived from crossing healthy male and healthy female plants did not contain CMV, whereas a number of plants derived from all of the other crosses were infected by the virus (Table 2). The incidence of CMV in the seedlings obtained by crossing infected males with healthy females was $14.5 \%$, which was similar to the infection level observed in the parent plant seed lot (Tables 1 and 2). CMV infection of progeny from crosses between infected male and infected female plants and healthy male and infected female plants was lower than that of the parent plant seed lot (Tables 1 and 2). Overall, however, these results corroborate the observations made with the parent plant seed lot and confirm that CMV was seed transmitted in spinach. Most importantly, the results demonstrate that CMV in spinach seed can be derived from both male and female parents.

Distribution of CMV in spinach reproductive organs and seed tissues. Electron microscopy investigations of ovary wall
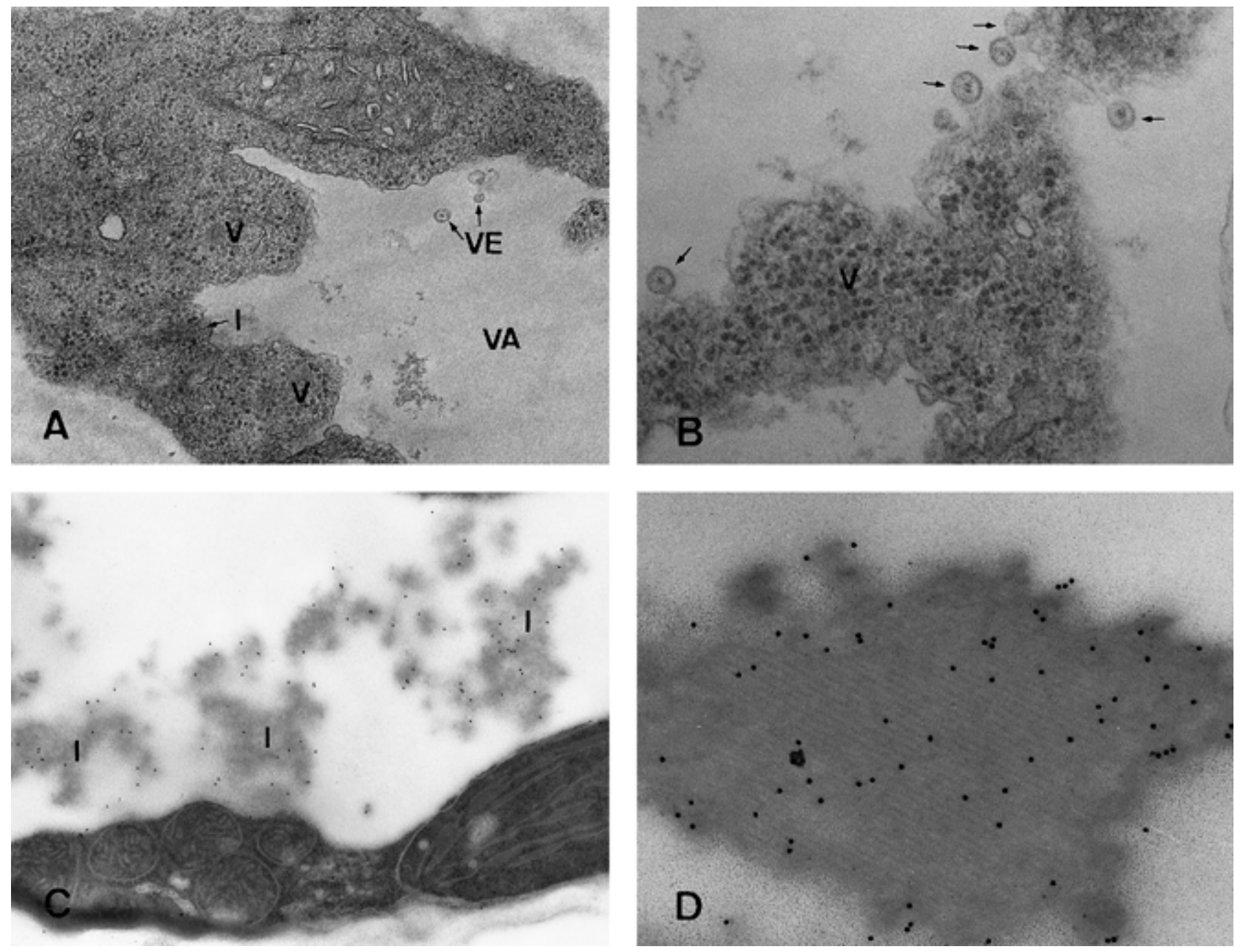

Fig. 1. Electron micrographs of thin sections of ovule integument cells from cucumber mosaic virus (CMV)-infected spinach. A, Partial view of an integument cell showing CMV particles and associated structures in the cytoplasm. Virus particles (V) appear as discrete spheres associated with amorphous inclusion bodies (I) in the cytoplasm, and fibril-containing vesicles (VE) are present in the central vacuole (VA). 30,000×. B, High magnification of CMV particles (V) and characteristic vesicles (arrows) associated with the tonoplast. 70,000×. C, Immunogold-labeled ovule integument cell showing gold particles specifically localized in the areas of the cytoplasm containing the virus and in the central vacuole where amorphous and crystalline inclusions (I) occurred. 22,400x. D, High magnification of crystalline inclusion bodies in the central vacuole labeled with gold particles. 66,000x. 
and ovule tissues from infected spinach revealed CMV particles in the cytoplasm of ovary wall parenchyma and epidermal cells, as well as in both the integument and the nucellus cells of the ovule. These virus particles appeared as discrete spheres, $28 \mathrm{~nm}$ in diameter, and were often associated with amorphous inclusion bodies (Fig. 1A). In addition, fine fibril-containing vesicles occurred in the central vacuole along the tonoplast and appeared to be derived from the tonoplast (Fig. 1B). Immunogold-labeling studies of infected ovule tissues revealed that gold particles were specifically localized in the cytoplasm, where virus particles were present, and in the central vacuole, where amorphous and crystalline inclusions occurred (Fig. 1C and D). No gold particles were located in chloroplasts or mitochondria. The presence of virusinduced inclusions and fibril-containing vesicles suggests that CMV actively replicated in the cells of spinach integument and nucellus tissues.

Ultrastructural analyses of anther tissues from infected spinach revealed that CMV particles were present in the cytoplasm of anther parenchyma, epidermis, and tapetum cells. Unlike those in the ovule cells, these virus particles occurred as aggregates, often near Golgi bodies (Fig. 2A). Fibril-containing vesicles along the tonoplast and amorphous inclusions in the central vacuole also were observed (data not shown). Immunogold particles in these cells were localized specifically in both the ground cytoplasm and the central vacuole, where amorphous inclusions existed (Fig. 2B). The occurrence of CMV particles and fibril-containing vesicles in anther parenchyma and tapetum cells suggests that the virus actively replicated in these tissues. The presence of CMV particles in diverse anther tissues suggests that infection might have occurred at the beginning of anther development and that pollen grains might have become infected from the pollen mother cells.

Electron microscopy studies also revealed that CMV particles were distributed randomly in the cytoplasm of infected seed-coat cells (Fig. 3A). However, fibril-containing vesicles and electrondense inclusions rarely were observed in these cells. Immunogold

TABLE 1. Cucumber mosaic virus (CMV) infection of spinach seeds, determined by seed grow-out and enzyme-linked immunosorbent assay (ELISA)

\begin{tabular}{lccc}
\hline Experiment $^{\mathrm{y}}$ & Infected seedlings $^{\mathrm{z}}$ & Total seedlings & Infection rate (\%) \\
\hline 1 & 27 & 180 & 15.0 \\
2 & 18 & 128 & 14.1 \\
3 & 14 & 92 & 15.2 \\
4 & 8 & 50 & 16.0 \\
5 & 12 & 86 & 13.9 \\
Total & 79 & 536 & 14.8 \\
\hline
\end{tabular}

${ }^{y}$ Seeds for all experiments were from a single seed lot and were planted in flats at a rate of $\sim 800$ seeds per square meter. Visual observations and ELISA were conducted 6 weeks after planting.

${ }^{\mathrm{z}}$ A seedling was considered CMV positive when the mean absorbance $\left(A_{405}\right)$ of duplicate samples was three times greater than the absorbance from uninfected plant controls.

TABLE 2. Cucumber mosaic virus (CMV) infection rate of spinach progeny seedlings derived from different crosses

\begin{tabular}{lccc}
\hline Cross $^{\mathrm{y}}$ & $\begin{array}{c}\text { Infected } \\
\text { seedlings }^{\mathrm{z}}\end{array}$ & $\begin{array}{c}\text { Total } \\
\text { seedlings }\end{array}$ & $\begin{array}{c}\text { Infection } \\
\text { rate }(\%)\end{array}$ \\
\cline { 1 - 2 } Healthy male $\times$ healthy female & 0 & 138 & 0 \\
Infected male $\times$ infected female & 18 & 184 & 9.8 \\
Healthy male $\times$ infected female & 15 & 184 & 8.2 \\
Infected male $\times$ healthy female & 17 & 117 & 14.5 \\
\hline
\end{tabular}

${ }^{y}$ Each cross consisted of 5 to 10 spinach plants of each parent. Experiments were conducted in separate greenhouses to prevent uncontrolled cross-pollination.

${ }^{z} \mathrm{CMV}$ infection was determined by seed grow-out and enzyme-linked immunosorbent assay tests. A seedling was considered CMV positive when the mean absorbance $\left(A_{405}\right)$ of duplicate samples was three times greater than the absorbance from uninfected plant controls. labeling revealed the areas in the ground cytoplasm in which virus particles occurred (Fig. 3B). Because the seed coat is derived from integuments, CMV in the seed-coat cells probably was derived from the infected ovule tissue during seed development.

Some spinach tissues, including embryos, endosperm, and pollen grains, were difficult to manipulate and prepare for electron microscopy. Therefore, an RT-PCR method was adapted to detect CMV in these tissues. When total nucleic acid extracted from embryos of seeds produced by CMV-infected plants was used as template material for RT-PCR, cDNA fragments representing the CMV CP gene and its flanking sequences were amplified (Fig. 4). The resulting cDNA fragments were of the expected size ( 860 bp) and comigrated in agarose gels with products derived from the CMV-infected positive control (Fig. 4, lane 2). No PCR product was obtained from the healthy embryo extracts (Fig. 4, lane 3). Furthermore, CMV CP gene cDNA was amplified to detectable levels with extracts from as few as five embryos (Fig. 4, lane 7). CMV cDNA also was amplified from nucleic acid extracts of some endosperm and pollen samples in analogous experiments, indicating the endosperm tissues also harbored CMV, and there were detectable levels of the virus in or on the pollen (data not shown). Taken together, RT-PCR and electron microscopy results revealed that CMV infected and accumulated in spinach reproductive tissues as well as seed tissues and supported the observation that both male and female parent plants can serve as infection sources of CMV.

Partial molecular characterization of the spinach CMV isolate. Cloned cDNA fragments representing the $\mathrm{CP}$ gene and flank-
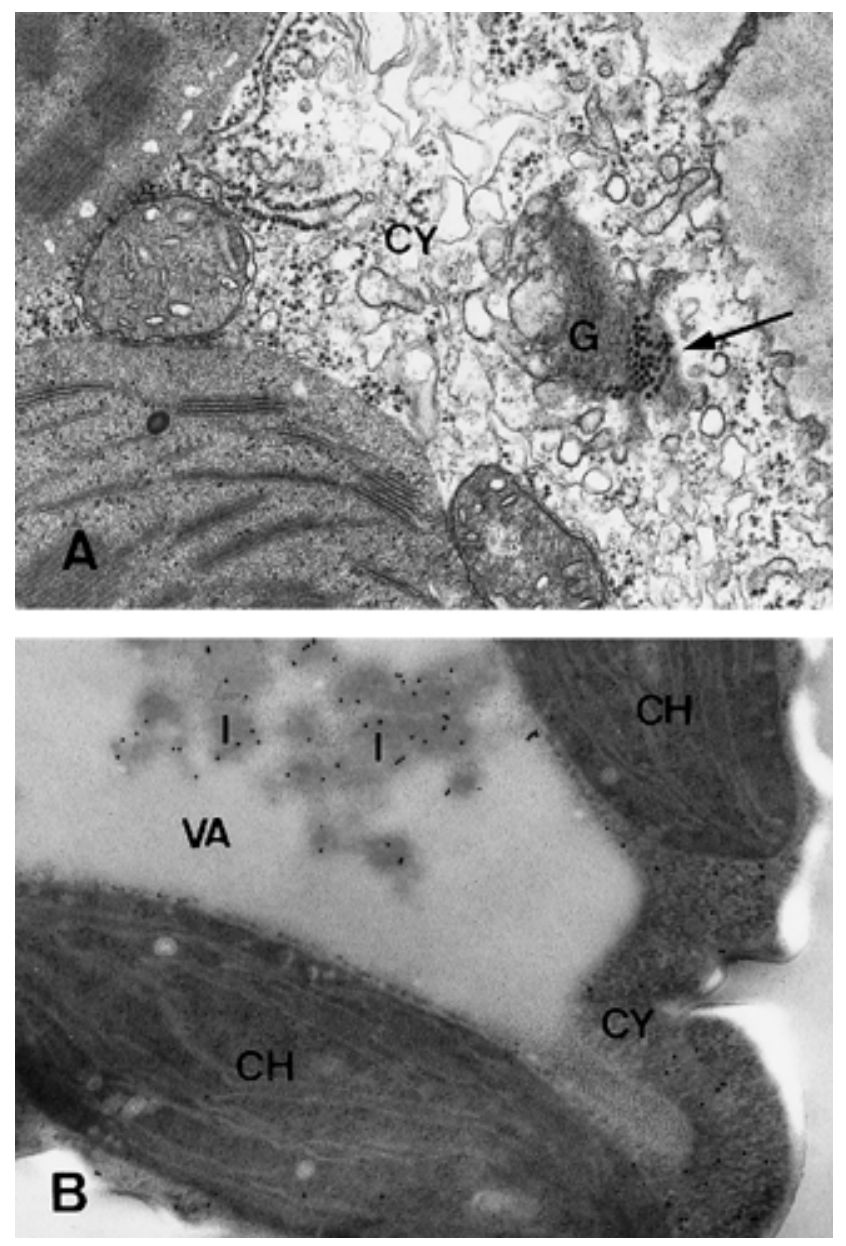

Fig. 2. Electron micrographs of anther cells from cucumber mosaic virus (CMV)infected spinach. A, Anther cell showing aggregates of CMV particles (arrow) embedded in an amorphous inclusion near a Golgi body (G) in the cytoplasm (CY). 28,000×. B, Immunogold-labeled anther cell showing gold particles specifically localized in the ground cytoplasm (CY) and amorphous inclusions (I) in the central vacuole (VA). $\mathrm{CH}=$ chloroplast. $35,000 \times$. 
ing sequences amplified from nucleic acid extracts of infected spinach leaves were sequenced completely. Analysis of $14 \mathrm{cDNA}$ clones revealed two sequence variants of CMV, designated SP103 and SP104, that coexisted in 7 of the 8 spinach parent plants from the CMV-infected breeding line (Fig. 5). These two sequence variants were the only variants identified from parent and progeny plants, and they shared $98 \%$ identity within their $\mathrm{CP}$ gene and flanking nucleotide sequences. Although the length of the $\mathrm{CP}$ coding sequences for these sequence variants was the same, SP103 had a longer $5^{\prime}$ flanking region than SP104, resulting in a total amplified length of 873 bases compared to 867 bases amplified from SP104 (Fig. 5). Interestingly, similar analysis of the CP gene and flanking regions of a previously identified but uncharacterized severe isolate from a commercial spinach field in Texas revealed that its characterized region was identical to SP104 (data not shown). When compared to some known strains of CMV, the CP gene and flanking sequences of the CMV variants examined in this study had greater than $96 \%$ identity with members of CMV subgroup II and less than $75 \%$ identity with subgroup I strains. These results indicate that this spinach-infecting CMV belongs to CMV subgroup II.

SP103 and SP104 were the only two sequence variants identified throughout these studies. To examine the possibility that these sequence variants represented two distinct CMV isolates in mixed infection, we determined the distribution of cDNA clones representing SP103 and SP104 in CMV-infected spinach parent and progeny plants (Table 3 ). In addition to cDNA sequencing, variants
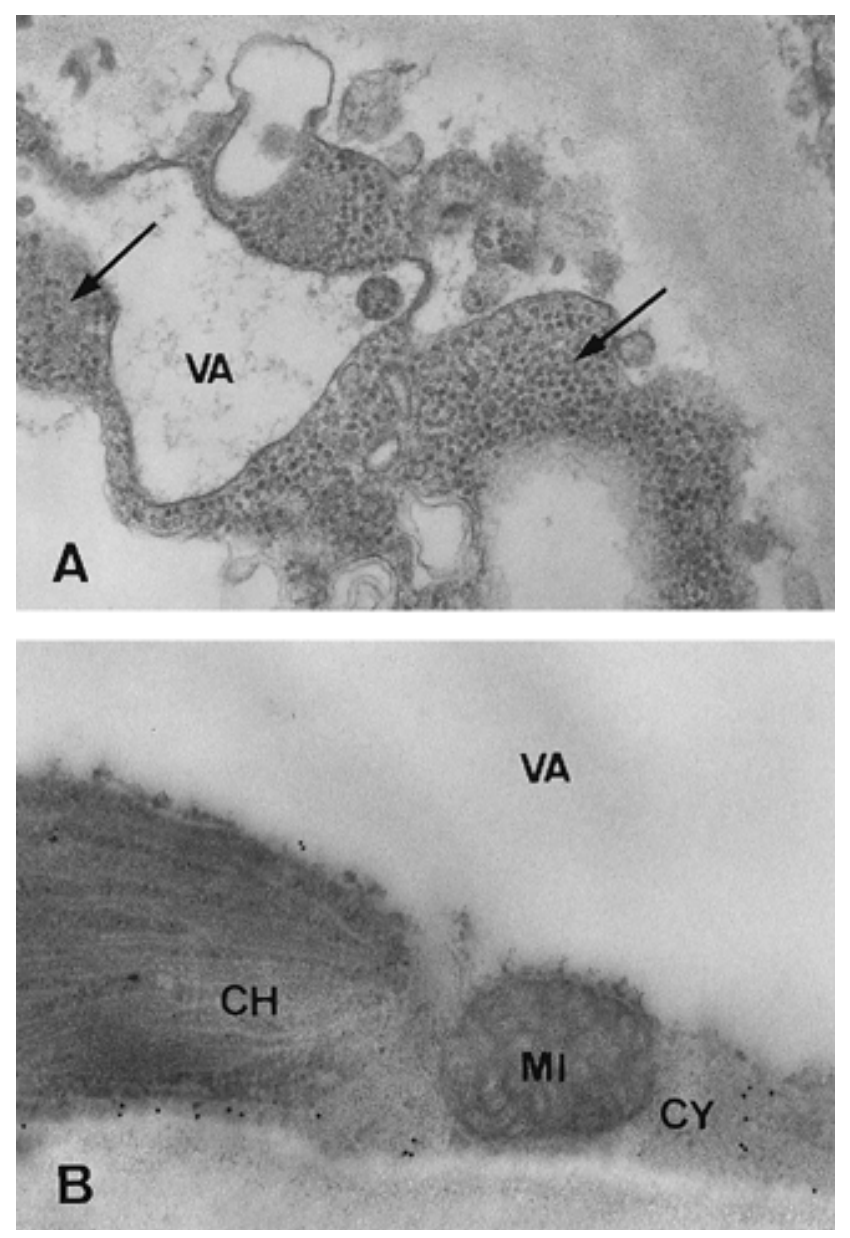

Fig. 3. Electron micrographs of cucumber mosaic virus (CMV)-infected seedcoat cells. A, Virus particles (arrows) randomly distributed in the cytoplasm of the seed-coat cell. No fibril-containing vesicles are present in the central vacuole (VA). 40,000×. B, Immunogold labeling appears only in the cytoplasm $(\mathrm{CY})$ areas containing $\mathrm{CMV}$; both the chloroplast $(\mathrm{CH})$ and mitochondria (MI) are free of labeling. 35,000×.
SP103 and SP104 were distinguished by restriction endonuclease analysis. The CP gene of variant SP103 contains a unique MluI site 516 bases from the start codon that is not present in SP104 (Fig. 5). Sequencing or restriction endonuclease analyses of 46 clones derived from $8 \mathrm{CMV}$-infected spinach parent plants with seedborne CMV revealed that 34 clones represented variant SP103, and 12 clones were from variant SP104. In only one case (spinach parent plant 4), in which eight clones were examined, was one variant (SP103) identified independently of the other. Of the clones derived from plant 5, isolates SP103 and SP104 were represented equally (Table 3 ). Although a slightly greater number of clones representing SP104 was observed in plants 1 and 2, characterization of clones derived from the other four plants (numbers $3,6,7$, and 8) suggested that variant SP103 predominated in these plants. cDNA clones derived from two CMV-infected spinach progeny plants were analyzed by restriction endonuclease mapping. The results demonstrated that among 14 clones derived from 1 progeny plant, 11 clones represented CMV variant SP103, and 3 clones were from SP104 (Table 3). However, among six clones from the second progeny plant, CMV variant SP104 was not represented (Table 3). These results strongly suggested that CMV variants SP103 and SP104 coexisted in the infected parent plants and were transmitted through the seed to the progeny plants, with variant SP103 predominating.

\section{DISCUSSION}

The results presented here represent the first confirmed report of CMV seed transmission in spinach. CMV is known to pose a significant threat to spinach production, and the presence of seedborne sources of CMV inoculum increases the risk of disease problems in this important leafy vegetable crop. Analysis of seed from one spinach breeding line demonstrated an incidence of CMV infection of nearly $15 \%$. In addition, preliminary studies conducted in our laboratory with another breeding line indicated an infection incidence of $\sim 20 \%$ (data not shown). These results suggest that seed transmission of CMV in spinach may be common.

Because spinach is a dioecious plant, it was possible to examine some aspects of the mechanism of CMV seed transmission by separately analyzing various reproductive and seed tissues and by analyzing seed obtained from crosses between healthy and/or in-

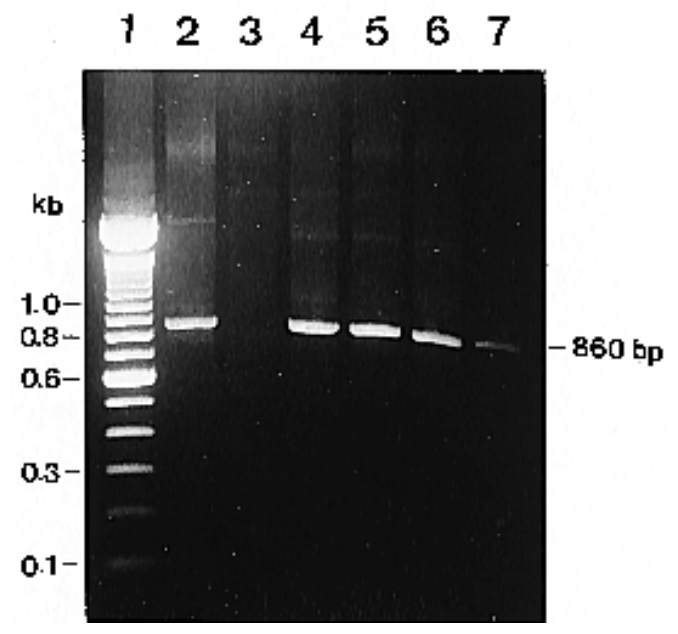

Fig. 4. Agarose gel electrophoresis of polymerase chain reaction products representing the cucumber mosaic virus (CMV) coat protein gene and its flanking sequences, amplified from CMV-infected spinach embryo tissue. Lane 1, 100-bp DNA ladder (Gibco BRL, Gaithersburg, MD). Lane 2, positive control, representing CMV sequences amplified from total nucleic acid extracted from CMV-infected spinach leaves. Lane 3, negative control derived from embryos of a CMV-free breeding line. Lanes 4 through 7, cDNA products from CMV-infected embryos from which total nucleic acids were extracted as templates from $100,50,25$, and 5 embryos, respectively. 
fected plants. These studies demonstrated that CMV was present in all reproductive and seed tissues examined and that the virus in progeny plants could be derived from infected male or female parent plants.

Previous work has shown that seed transmission of plant viruses through infected embryos occurs when a virus is present in reproductive tissues prior to embryogenesis, resulting in indirect embryo invasion, or when a virus is introduced during embryo-

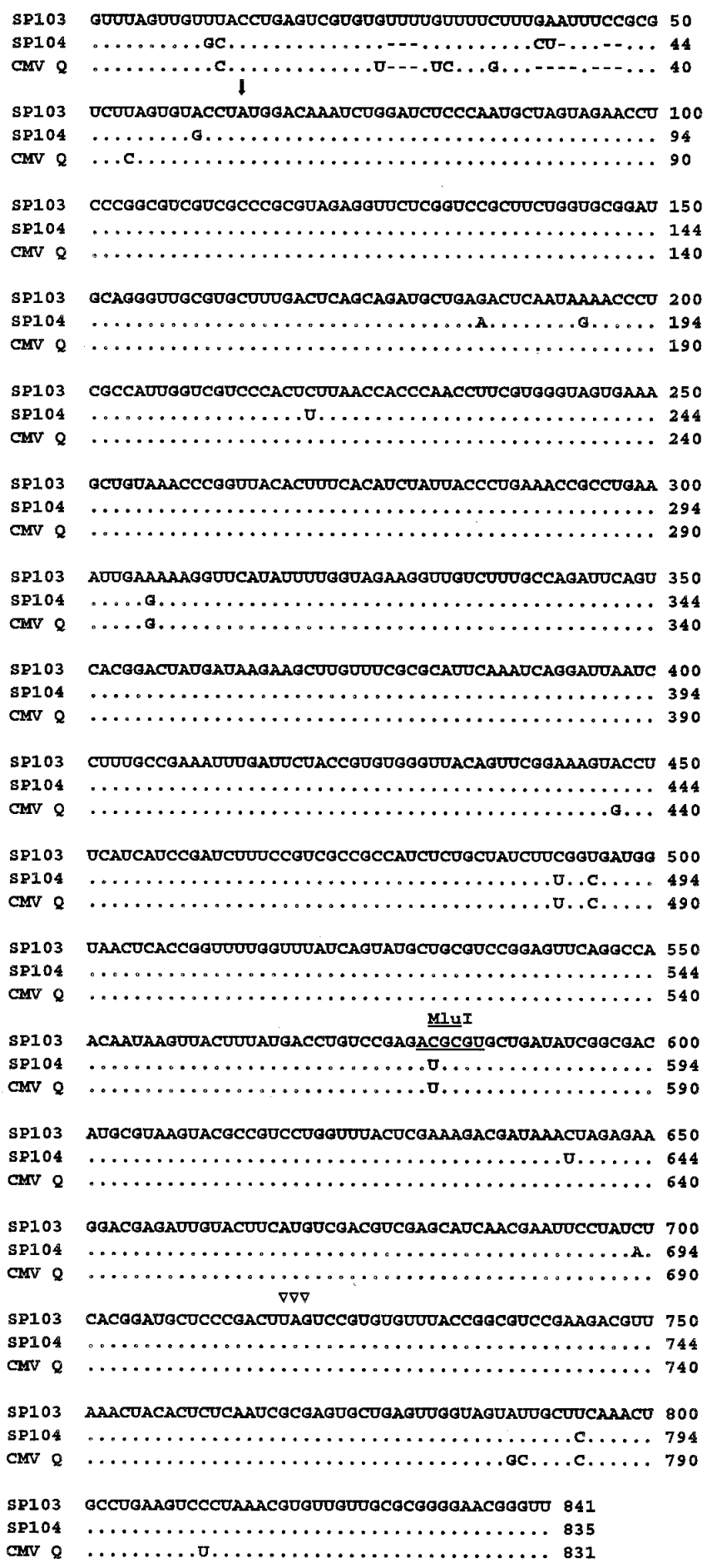

Fig. 5. Multiple alignment of coat protein (CP) genes and flanking sequences of cucumber mosaic virus (CMV) variants SP103 and SP104 with strain CMVQ. Dots indicate regions where nucleotide sequences are identical to those of SP103; dashes indicate gaps. The arrow points to the start position of the CP gene, and the triple arrowhead indicates the stop codon for the CP gene. The $M l u \mathrm{I}$ restriction endonuclease site present in SP103 is indicated. genesis, resulting in direct embryo invasion (17). Ultrastructural studies presented here indicate that CMV can invade both maternal and paternal spinach reproductive organs. The observation of virus particles in the cytoplasm and fibril-containing vesicles along the tonoplasts of infected ovary wall cells, ovule integument and nucellus cells, and anther parenchyma, epidermal, and tapetum cells supports the suggestion that CMV can replicate in these tissues, because similar vesicles in other infected plants contain viral dsRNA, a replication intermediate formed during synthesis of the viral genome (16). In addition, immunogold labeling of amorphous inclusions in the cytoplasm and crystalline inclusions in the central vacuoles of ovule and anther cells suggests that these inclusions contain viral structural proteins.

Virus infection of embryos is essential for virus seed transmission in most systems $(17,37)$, although virus presence in or on the seed coat and in endosperm tissues does play a role in the seed transmission of some viruses $(2,36)$. Much of the existing evidence indicates that a virus invades female gametophyte tissues from surrounding maternal cells. For instance, seed transmission of tobacco ringspot nepovirus (TRSV) in soybean depends on the virus moving into meristematic tissue and infecting the megaspore mother cell (41). TRSV aggregates were localized in the walls of the embryo sac and the generative cells, further suggesting invasion by the virus from infected maternal cells (17). In another example, pea seed-borne mosaic virus directly invaded pea embryos early in development, multiplied in the embryo tissue, and persisted during seed maturation (38). In the current study, CMV sequences were amplified consistently from embryos of infected seeds. Because the megagametophyte becomes symplastically isolated from the surrounding tissue quite early in the development of the flower and theoretically should not become infected after that time, the presence of CMV in embryos suggests that the virus is probably derived either from indirect invasion of the megaspore mother cell prior to the formation of any physical boundary or from indirect invasion by infected pollen grains during fertilization.

The presence of CMV in ovule integument and nucellus tissues, pollen grains, and other reproductive tissues, combined with our findings that CMV transmission through spinach seed occurred after crosses between infected female or male parent plants, clearly indicates that indirect embryo invasion occurs, although the possibility of direct embryo invasion cannot be ruled out entirely by these studies. In fact, we were somewhat surprised to observe lower rates of seed transmission from crosses involving infected female parents compared to the cross of healthy female and infected male parents. Likewise, we might have expected a higher seed infection rate from crosses in which both parents were infected. The results may reflect reduced viability of the infected egg cell and might suggest that the major determinant in spinach seed transmission of CMV is the infection of the zygote from

TABLE 3. Identification of cucumber mosaic virus (CMV) sequence variants in spinach parent and progeny plants, determined by cDNA analysis ${ }^{\mathrm{x}}$

\begin{tabular}{|c|c|c|c|c|c|c|c|c|c|c|c|c|}
\hline \multirow{2}{*}{$\begin{array}{l}\text { CMV } \\
\text { sequence } \\
\text { variant }\end{array}$} & \multicolumn{8}{|c|}{ Parent plant ${ }^{\mathrm{y}}$} & \multicolumn{3}{|c|}{$\begin{array}{c}\text { Progeny } \\
\text { plant }^{\mathrm{z}}\end{array}$} & \multirow[b]{2}{*}{ Total } \\
\hline & 1 & 2 & 3 & 4 & 5 & 6 & 7 & 8 & Total & 1 & 2 & \\
\hline SP103 & 2 & 1 & 6 & 8 & 2 & 6 & 5 & 4 & 34 & 11 & 6 & 17 \\
\hline SP104 & 3 & 2 & 1 & 0 & 2 & 1 & 1 & 2 & 12 & 3 & 0 & 3 \\
\hline
\end{tabular}

${ }^{\mathrm{x}} \mathrm{CMV}$ infection was determined by seed grow-out and enzyme-linked immunosorbent assay in both parent and progeny plants when seedlings reached the 5-leaf stage. cDNA representing the CMV coat protein gene and flanking regions was produced by reverse transcription-polymerase chain reaction amplification, cloned, and sequenced or restriction endonuclease mapped.

${ }^{\text {y }}$ cDNA clones were analyzed by nucleotide sequencing or $M l u \mathrm{I}$ restriction endonuclease mapping.

${ }^{\mathrm{z}}$ Progeny spinach plants were derived from a cross between infected male and infected female plants. cDNA clones were characterized by $M l u I$ restriction endonuclease mapping. 
infected pollen. In agreement with our results, pollen transmission of bean common mosaic virus (BCMV) was more effective than ovule transmission in at least one bean cultivar (21), and similar results have been reported with alfalfa mosaic virus (11).

As early as 1918, BCMV was thought to be carried by pollen and cause seed infection by passing from the germ tube into the style during pollination (29). Existing evidence indicates that viruses can be transmitted directly to embryos from pollen when flowers of healthy plants are pollinated from infected plants (12, $20,21,38)$. In addition, surface contamination of pollen by some viruses was reported to result in seed transmission (14). In the current study, we used a RT-PCR method to identify CMV from spinach pollen. This method did not allow us to determine whether the virus was present on the surface of or within the pollen grains. However, taken together with results of ultrastructural studies and ELISA from the progeny plants produced by crossing healthy female and infected male plants, these data again strongly support the notion of indirect embryo infection during pollination.

As part of our work to understand CMV seed transmission in spinach, we partially characterized this virus isolate. Nucleotide sequencing of the $3^{\prime}$ half of RNA 3 from a number of CMV strains has revealed highly conserved regions that subsequently have been used to design primer pairs for RT-PCR amplification of the $\mathrm{CP}$ gene and its $5^{\prime}$ and $3^{\prime}$ flanking sequences $(5,26,30,40)$. We used the same information to design a degenerate primer pair to amplify this region of the CMV isolate from infected spinach. Based on sequencing and restriction endonuclease mapping of cDNA clones derived from parent and progeny seedlings, the seed-transmitted CMV from spinach belongs to subgroup II. More interesting, however, was the identification of two specific sequence variants, designated SP103 and SP104, that coexisted in most of the analyzed plants. The sequence variants were highly conserved but did contain a number of differences in their CP gene and flanking regions. Whereas a plant virus may possess populations of virus RNAs with potentially different sequences, our consistent observation of only two sequence variants suggests the possibility of a mixed infection. Although we have identified a virus in spinach samples from a field in Texas whose $\mathrm{CP}$ gene and flanking regions were identical to that of SP104 and we occasionally have cloned only SP103 from infected spinach seedlings grown from the breeding line examined in this study, we cannot confirm these two virus variants as distinct isolates. More work is necessary to separate these variants and study them in single and mixed infections.

Seed transmission determinants for a few viruses, including some CMV strains infecting $P$. vulgaris, have been mapped to virus genomic RNAs $(7,15)$. Although work is currently being conducted to determine whether SP103 and SP104 represent distinct virus isolates and the possible significance of a mixed infection for seed transmission, the long-range goals of this project include the complete characterization of spinach-infecting CMV and identification of the virus determinants of seed transmission.

\section{ACKNOWLEDGMENTS}

This research was supported in part by a grant from the Arkansas Science and Technology Authority (Grant 94-B-05). Approved for publication by the director of the Arkansas Agricultural Experiment Station, manuscript 96118. We thank T. Morelock for supplying spinach seed and advice on experiment design; P. Palukaitis and M. Roossinck for insightful discussions; A. Kline and S. Goeke for technical assistance; and B. Murphy for critical review of the manuscript.

\section{LITERATURE CITED}

1. Bos, L., and Maat, D. Z. 1974. A strain of cucumber mosaic virus, seedtransmitted in beans. Neth. J. Plant Pathol. 80:113-123.

2. Broadbent, L. 1965. The epidemiology of tobacco mosaic. XI. Seedtransmission of TMV. Ann. Appl. Biol. 56:177-205.

3. Davies, C., and Symons, R. H. 1988. Further implications for the evo- lutionary relationships between tripartite plant viruses based on cucumber mosaic virus RNA 3. Virology 165:216-224.

4. Devergne, J.-C., and Cardin, L. 1973. Contribution a l'etude du virus de la mosaique du concombre (CMV). IV. Essai de classification de plusieurs isolats sur la base deleur structure antigenique. Ann. Phytopathol. 5:409-430.

5. Ding, S.-W., Anderson, B. J., Haase, H. R., and Symons, R. H. 1994. New overlapping gene encoded by the cucumber mosaic virus genome. Virology 198:593-601.

6. Doolittle, S. P., and Walker, M. N. 1925. Further studies on the overwintering and dissemination of cucurbit mosaic. J. Agric. Res. 31:1-58.

7. Edwards, M. C. 1995. Mapping of the seed transmission determinants of barley stripe mosaic virus. Mol. Plant-Microbe Interact. 8:906-915.

8. Edwards, M. C., and Gonsalves, D. 1983. Grouping of seven biologically defined isolates of cucumber mosaic virus by peptide mapping. Phytopathology 73:1117-1120.

9. Edwards, M. L., and Cooper, J. I. 1985. Plant virus detection using a new form of indirect ELISA. J. Virol. Methods 11:309-319.

10. Francki, R. I. B., Mossop, D. W., and Hatta, T. 1979. Cucumber mosaic virus. CMI/AAB Description of Plant Viruses, No. 213 (No. 1 revised). Commonwealth Agricultural Bureaux, England.

11. Frosheiser, F. I. 1974. Alfalfa mosaic virus transmission to seed through alfalfa gametes and longevity in alfalfa seed. Phytopathology 64:102105.

12. Gold, A. H., Suneson, C. A., Houston, B. R., and Oswald, J. W. 1954. Electron microscopy and seed and pollen transmission of rod-shaped particles associated with the false stripe virus disease of barley. Phytopathology 44:115-117.

13. Gonda, T. J., and Symons, R. H. 1978. The use of hybridization analysis with complementary DNA to determine the RNA sequence homology between strains of plant viruses: Its application to several strains of cucumoviruses. Virology 88:361-370.

14. Hamilton, R. I., Leung, E., and Nichols, C. 1977. Surface contamination of pollen by plant viruses. Phytopathology 67:395-399.

15. Hampton, R. O., and Francki, R. I. B. 1992. RNA-1 dependent seed transmissibility of cucumber mosaic virus in Phaseolus vulgaris. Phytopathology $82: 127-130$.

16. Hatta, T., and Francki, R. I. B. 1981. Cytopathic structures associated with tonoplasts of cells infected with cucumber mosaic and tomato aspermy viruses. J. Gen. Virol. 53:343-346.

17. Johansen, E., Edwards, M. C., and Hampton, R. O. 1994. Seed transmission of viruses: Current perspectives. Annu. Rev. Phytopathol. 32:363386.

18. Kaper, J. M., and Waterworth, H. E. 1981. Cucumoviruses. Pages 257332 in: Handbook of Plant Virus Infections and Comparative Diagnosis. E. Kurstak, ed. Elsevier/North-Holland Publishing Co., New York.

19. Kim, K. S., and Fulton, R. W. 1984. Ultrastructure of Datura stramonium infected with an euphorbia virus suggestive of a whitefly-transmitted geminivirus. Phytopathology 74:236-241.

20. Mandahar, C. L. 1981. Virus transmission through seed and pollen. Pages 257-270 in: Plant Disease and Vectors: Ecology and Epidemiology. K. Maramorosch and K. F. Harris, eds. Academic Press, New York.

21. Medina, A. C., and Grogan, R. G. 1961. Seed transmission of soybean mosaic virus. Phytopathology 51:452-456.

22. Neegaard, P. 1977. Survey of seed-borne viruses. Pages 80-116 in: Seed Pathology. John Wiley \& Sons, New York.

23. Owen, J., and Palukaitis, P. 1988. Characterization of cucumber mosaic virus. I. Molecular heterogeneity mapping of RNA 3 in eight CMV strains. Virology 166:495-502.

24. Palukaitis, P., Roossinck, M. J., Dietzgen, R. G., and Francki, R. I. B. 1992. Cucumber mosaic virus. Adv. Virus Res. 41:281-348.

25. Pappu, S. S., Brand, R., Pappu, H. R., Rybicki, E. P., Gough, K. H., Frenkel, M. J., and Niblett, C. L. 1993. A polymerase chain reaction method adapted for selective amplification and cloning of $3^{\prime}$ sequences of potyviral genomes: Application to dasheen mosaic virus. J. Virol. Methods 41:9-20.

26. Pappu, S. S., Pappu, H. R., Niblett, C. L., and Bird, J. 1991. Molecular cloning and nucleotide sequencing of isolates of cucumber mosaic virus from bananas and plantains in Puerto Rico. (Abstr.) Phytopathology 81: 1154.

27. Piazzolla, P., Diaz-Ruiz, J. R., and Kaper, J. M. 1979. Nucleic acid homologies of eighteen cucumber mosaic virus isolates determined by competition hybridization. J. Gen. Virol. 45:361-369.

28. Quemada, H., Kearney, C., Gonsalves, D., and Slightom, J. L. 1989. Nucleotide sequences of the coat protein genes and flanking regions of cucumber mosaic virus strains C and WL RNA 3. J. Gen. Virol. 70:10651073.

29. Reddick, D., and Stewart, V. B. 1918. Varieties of beans susceptible to mosaic. Phytopathology 8:530-534. 
30. Rizos, H., Gunn, L. V., Pares, R. D., and Gillings, M. R. 1992. Differentiation of cucumber mosaic virus isolates using the polymerase chain reaction. J. Gen. Virol. 73:2099-2103.

31. Sambrook, J., Fritsch, E. F., and Maniatis, T. 1989. Molecular Cloning: A Laboratory Manual. 2nd ed. Cold Spring Harbor Laboratory Press, Cold Spring Harbor, NY.

32. Sanger, F., Nicklen, S., and Coulson, A. R. 1977. DNA sequencing with chain terminating inhibitors. Proc. Natl. Acad. Sci. USA 74:5463-5467.

33. Sharma, Y. R., and Chohan, J. S. 1974. Transmission of cucumis viruses 1 and 3 through seeds of cucurbits. Indian Phytopathol. 26:596-598.

34. Spurr, A. R. 1969. A low-viscosity epoxy resin embedding medium for electron microscopy. J. Ultrastruct. Res. 26:31-43.

35. Stace-Smith, R., and Hamilton, R. I. 1988. Inoculum threshold of seedborne pathogens: Viruses. Phytopathology 78:875-880.

36. Taylor, R. H., Grogan, R. G., and Kimble, K. A. 1961. Transmission of tobacco mosaic virus in tomato seed. Phytopathology 51:837-842.

37. Uyemoto, J. K., and Grogan, R. G. 1977. Southern bean mosaic virus: Evidence for seed transmission in bean embryos. Phytopathology 67:
1190-1196.

38. Wang, D., and Maule, A. J. 1992. Early embryo invasion as a determinant in pea of the seed transmission of pea seed-borne mosaic virus. J. Gen. Virol. 73:1615-1620.

39. Wang, R. Y., Gergerich, R. C., and Kim, K. S. 1993. Noncirculative transmission of plant viruses by leaf-feeding beetles. Phytopathology 82:946950.

40. Wylie, S., Wilson, C. R., Jones, R. A. C., and Jones, M. G. K. 1993. A polymerase chain reaction assay for cucumber mosaic virus in lupin seeds. Aust. J. Agric. Res. 44:41-51.

41. Yang, A. F., and Hamilton, R. I. 1974. The mechanism of seed transmission of tobacco ringspot virus in soybean. Virology 62:26-37.

42. Yang, Y., Correll, J. C., Morelock, T. E., and Anderson, E. J. 1993. Characterization of a seed-transmitted cucumber mosaic virus (CMV) isolate from spinach (Spinacia oleracea L.). (Abstr.) Phytopathology 83:1403.

43. Yang, Y., Kim, K. S., and Anderson, E. J. 1995. Ultrastructural studies on seed transmission of cucumber mosaic virus in spinach. (Abstr.) Phytopathology $85: 1184$. 